\title{
Guide to Large Scale Production of Moringa oleifera (Lam.) for Sustainable Aquaculture Development in Nigeria: Prospects and Challenges.
}

\author{
${ }^{1}$ Adesina, B. T., ${ }^{2}$ Oguntuga, O. A., ${ }^{2}$ Raimi, K. A. A. and ${ }^{3}$ Ogunremi, J. B \\ ${ }^{1}$ Department of Fisheries and Wildlife Management, Osun State University, Osogbo, Nigeria. \\ ${ }^{2}$ Department of Aquaculture and Fisheries Management, University of Ibadan, Nigeria. \\ ${ }^{3}$ Department of Biological Sciences, Ondo State University of Science and Technology, \\ Okitipupa, Nigeria. \\ Correspondence author: isajin1999@yahoo.com,Tel:+2348038357765
}

\begin{abstract}
Aquaculture is one of the fastest growing food production sectors to every household in Nigeria. Products from aquaculture such as fish food supply protein to household protein. However, biosafety of food products from aquaculture is now considered as public health concern in Nigeria. This is due to the nature and component of materials used as rearing facilities on the fish farm. Elimination of unwanted fishes and other predators is a common practice among fish farmers in Nigeria prior to stocking of desirable fish fingerlings. The use of synthetic pesticides to eliminate unwanted fishes and other predators in pond is persistent and could get into the food chain. Thus, the use of environmentally safe natural pesticides as an alternative is being embraced in aquaculture because they have a short time of toxicity disappearance and biodegradable. This will enhance the principles of sustainable aquaculture production and its management in Nigeria. In Southwestern Nigeria, there is little or no information on commercial production of Moringa oleifera for aquaculture purpose. There is the need for future development on Moringa production on commercial scale in Southwestern Nigeria and elsewhere in the tropics for sustainable aquaculture development. The paper therefore reviewed possible guide to Moringa oleifera production, methodology for its potential application in sustainable aquaculture development in Southwestern Nigeria. Possible prospects and challenges to encounter during commercial production were discussed.
\end{abstract}

Keywords: Moringa oleifera, commercial, Sustainable aquaculture, Southwestern Nigeria

\section{INTRODUCTION}

The tree, Moringa oleifera Lam. has for many years been considered to be one of the most important of those that have had the description 'multi-purpose' attached to them. However, with the exception of large scale cultivation of the tree in India for the production of green, immature pods as a vegetable, there have been few attempts to commercialize the tree for the other products available from it viz.: oil for cosmetic and edible purposes, natural coagulant available from the seeds and the leaves as an alternative green vegetable source for human and animal consumption (Sutherland et al., 2001). This attempt was to make people aware of the difficulties 
involved in exploiting new product developments and to point out those areas where the knowledge base is not strong (Sutherland et al., 2001). But today, new song was sung on Moringa oleifera production as a new product due to improvement in awareness, advocacy and promotion of Moringa oleifera in developing world as tree of sustainable future in agricultural development and household uses. Moringa oleifera is a highly nutritive multipurpose plant grown for fresh vegetable, livestock fodder and for dairy cows in Nicaragua, green manure, biogas, medicine, bio-pesticide, seed production and water treatment, oil and as potential organic piscicide in aquaculture pond management (Fuglie, 1999; Adesina, 2008; Adesina et al., 2008; Adesina and Omitoyin, 2011; Mendieta-Araica, 2011; Nouman et al., 2012). All those attributes to Moringa oleifera are not yet explored on large scale in Nigeria; hence the present study is justifiable.

However, in Southwestern Nigeria, there is little or no information on commercial production of Moringa oleifera for aquaculture purpose. The paper therefore reviewed possible guide to Moringa oleifera production methodology for its potential application in sustainable aquaculture development in Southwestern Nigeria. Possible prospects and challenges to encounter during commercial production were discussed.

\section{Importance Of The Guide To Moringa Oleifera Growers For Future Sustainable Use In Aquaculture Development}

In as much as the awareness and advocacy for Moringa oleifera are on the increase, there is the need to inform the fish farmers on the need to be properly educated on the possible production of Moringa oleifera on a large scale for sustainable aquaculture development. They will be familiar with the production processes and acquire necessary skills on how to plant and process the plant for fish pond management and fish feed supplement. In aquaculture, fish farmers always encountered predatory problem during the stocking of new fish species. Most often, fish farmers result to the use of synthetic chemicals which are non-biodegradable for effective fish production. The bio-safety of products from aquaculture is paramount to consumers of aquatic foods from aquaculture source. Moringa oleifera is biodegradable, environmental friendly and cost-effective and could be used as supplemental protein source for fishmeal and aquaculture pond management tool to wipe predators in fish pond prior to stocking with new fish species. Moringa oleifera could also be of public health concern as a result of fish production that could be consumed at household level in Nigeria.

\section{The Concept of the Guide to Aquaculturist (Fish farmers)}

This guide will give an insight to Moringa oleifera application in sustainable aquaculture production. It will also serve as future key concept to fish farmers on value addition of useful materials in aquaculture production.

\section{Agronomic Aspect of Moringa oleifera Production}

Moringa can be propagated from seeds or from mature cuttings (brown wood). Purchase or collect your supply of seeds from reliable sources. A good seed should be viable, clean and 
disease free. Seeds should not be stored over long periods as they lose viability (germination capacity) after about one year. There are around 4000 Moringa seeds (with their shell) in a kilo. Seeds may be sown in containers, in seedbeds or directly in the field (Sauveuret and Broin, 2010; Wikipedia 2013).

When the germination rate is high, this is the case with Moringa oleifera. In Togo for instance, in small holders' farms, the germination rate is more than $85 \%$ only 12 days after seeding (Sauveuret and Broin, 2010). In Nigeria, there was 95\% germination only 8days after planting, but when the temperature is high, germination takes place on the $5^{\text {th }}$ and $6^{\text {th }}$ days (Personal observation during planting of the seed in polythene bags) dampness of the soil, $10-20 \mathrm{ml}$ of water applied to each bag is recommended. At this stage, the young shoot or plant must be well protected from grasshoppers, locusts, termites and ruminants.

Watering must be done with extreme care to avoid collapse of the feeble plant due to pressure. Collapsed plants must be suitably supported. The young Moringa plants must be nursed for 4-6 weeks before transplanting, when they are about $30 \mathrm{~cm}$ high. Remove the polythene bag when transplanting ensuring that the roots of the plant are not damaged.

Hard woodcuttings of one meter long and at least 4 to $5 \mathrm{~cm}$ in diameter can also be used for propagation. When planted, one third of the stem must be buried in the soil. Plants produced with cuttings will not have a deep root system and will be more sensitive to wind and drought. Cuttings are also more sensitive to termite attacks.

\section{Nutritional Role of Moringa Leaf as Potential Fish Feed in Aquaculture}

There are no studies so far which report utilisation of Moringa leaves or seed meal as fish feed ingredients. Preliminary results from a trial in the laboratory, where Moringa leaf meal was used in Tilapia niloticus feeds, indicate growth-reducing effects at high levels of inclusion of raw leaf meal. Moringa plant parts have the potential to be a supplier of macro and micronutrients in a fish feed derived from a mixture of plant products (Francis et al., 2003). The high cost and fluctuating quality as well as the uncertain availability of fish meal have led to the need to identify alternative protein sources for fish feed formulation (Richter et al., 2003). Therefore, in order to attain more economically sustainable, environmentally friendly and viable production, research interest has been directed towards the evaluation and use of non-conventional sources of plant protein (Richter et al.,2003), where Moringa oleifera is also a promotable candidate in this regards.

A feeding trial was conducted in which the suitability of freeze-dried Moringa leaf meal ( $M$. oleifera) as an alternative protein source for Nile tilapia (Oreochromis niloticus L.) was evaluated (Richter et al ., 2003). Three experimental diets were formulated to contain Moringa Leaf Meal at levels of $10 \%, 20 \%$ and $30 \%$ of the total dietary protein which included only fish meal and wheat meal as protein sources (Richter et al., 2003). However, no feeding related mortality was observed during a 7-week feeding trial period. The diets with higher inclusion levels of Moringa leaves significantly depressed growth performance of $O$. niloticus. These results suggest that Moringa leaf meal can be used to substitute up to $10 \%$ of dietary protein in Nile tilapia without significant reduction in growth (Richter et al., 2003). 
Preliminary trial where Moringa leaf meal was used in Tilapia niloticus feeds indicates growthreducing effects at high level of inclusion of raw leaf meal (Francis et al 2003;Richter et al .,2003). However, $O$. niloticus feeding trial showed better performance when compared to leuceania in the diet of carp (Devaraj et al., 1986).

\section{Potential of Moringa oleifera as Organic Piscicides in Aquaculture Pond Management}

Piscicides are toxic substances used to kill potential predators or competitors in ponds prior to stocking and for elimination of infected fish populations (Bocek, 2004; Agbon et al., 2004). They are principally used in aquaculture as pond management tool in aquaculture. Among the synthetic piscicides are Ammonia, Calcium/Magnesium oxide, Trichlorfor (GESAMP, 1997; Bocek, 2004). The synthetic piscicides have been implicated to have caused bioaccumulation of fish organs and tissues, respectively (Fafioye, 2001). While the most commonly used nonsynthetic (biodegradable) piscicides are tea seed and mahua oil cake, which contained active ingredients such as sapogenin and glycoside and rotenone (Chiavyareesajja et al., 1997; Bocek, 2004, Agbon et al., 2004; Akinbulumo et al., 2004). However, sapogenin glucosides, rotenone and certain other biodegradable piscicides are toxic to animals including fish and humans. Although, these compounds are unlikely to present a significant risk under normal condition of use in aquaculture (FAO/NACA/WHO, 1999).

Rotenone from Derris elliptica root is the main piscicide used for controlling or eliminating pest fish internationally (Rowe, 2004). As a liquid formulation, its lethal concentration, mode of action and effectiveness under differing environmental circumstances has been well established and extensively documented (Lennon et al., 1970; Schnick, 1974, Davies and Shelton, 1983, Rowe, 2004, Agbon et al., 2004; Akinbulumo et al., 2004). It presents a hazard to workers; an inhalation may result in respiratory paralysis (GESAMP, 1997). The use of rotenone is strictly controlled by many countries such as USA, European Union, Canada and New Zealand (Rowe, 2004; Agbon et al., 2004). However, efforts are being intensified to search for other biodegradable piscicides in aquaculture which their effects may not cause bioaccumulation and biomagnification in organ and tissues of humans and the final consumer of aquatic food fish.

Currently, there is scanty information in literature as regards the use of fresh root-bark extracts of Moringa oleifera as an organic piscicide in aquaculture pond management in the developing world (Adesina \& Omitoyin, 2011). Moringa oleifera is a tree belonging to the family Moringaceae, usually growing outside the forest areas of south-western Nigeria (Adesina et al. 2008). The tree is under-utilized and contains several toxic compounds, such as phenol, tannins, saponins, glucosinolates, oxalic acid, lectins, moringine and moringinine (alkaloids), pterygospermin, spirochin and benzyisothiocyanate (Berger et al. 1984; Grabow et al. 1985; Makkar \& Becker 1997; Fuglie 2001; Fahey 2005; Wise 2006). Moringa oleifera is suggested as an alternative to synthetic piscicides because it is commonly available, is less expensive for fish farmers and has a lower toxicity against non-target species. Its piscicidal potential is embedded in the root-bark which contains the alkaloids that act on the nervous system of fish and other terrestrial animals (Fuglie 2001; Adesina 2008). 
Adesina, Oguntuga, Raimi and Ogunremi

\section{Prospects of Commercial Production of Moringa oleifera for Sustainable Aquaculture Production}

Moringa oleifera could be another novel product to aquaculture development in Nigeria. Possibility of production of fish feed from Moringa products such as the leaves could be a new wave in aquaculture fish feed production. Moringa leaves are rich in protein, vitamins, minerals and essential amino supplement required for fish growth. The use of Moringa oleifera products in fish feed manufacturing company could be advantageous to the communities where Moringa will be planted. It could serve as source of income and employment opportunities for the youth in such communities

\section{Production of Organic Baits and Piscicide by Moringa Manufacturing Company for Aquaculture Uses}

Organic Baits and Piscicicide manufacturing companies could be additional asset to the communities where Moringa is planted on a large scale. As this would add value to the community development on the provision of access roads and power supply; these serve as a drive to economic growth and development in communities where the companies is sited.

\section{Oil production for Aquaculture uses}

The oil from Moringa could be used as additional fish feed ingredient for sustainable aquaculture, the oil could also serve as anti stressor in transportation of fish.

This could be possible once Moringa oleifera is commercialized for aquaculture development. The products from root-bark and seeds could be incorporated as disinfectant material in fishpond; ashes from the leaves could be used as liming material in fish pond. This is to mention just a few of the future prospects of Moringa in sustainable aquaculture in Nigeria.

\section{Challenges of Moringa oleifera Production on large scale for Sustainable Aquaculture Production}

Although, the markets for the alternative products are very different, there is one constraint to development that is common to them all and that is that they are all considered to be 'new' products. As such, the development of any new product brings with it a host of interlinked constraints. These include: Finance, Research and Development, Market awareness and Regulatory approval.

\section{Finance}

This is perhaps one of the most significant constraints. The development of a new product on any scale can require a significant financial investment. Unless this development is being undertaken by an existing company/organisation, it is not an easy matter to obtain funding for a starting up company to produce a product that has, initially, no guarantee of a market. 


\section{Research and development}

This is a very broad yet significant constraint. Although, in the case of Moringa, there is much published information on the 'applications' of the alternative products much of this may be considered as being solely of a 'scientific' nature. This is a good starting point as there would be no reason to develop a product that showed no potential application, however, there is little research published on what may be considered more practical issues. For example, there is a lot of information on how to propagate Moringa but very little on how the tree should be managed. If left untouched, Moringa can grow to in excess of $10 \mathrm{~m}$ in height, this clearly is unsatisfactory when it comes to harvesting of the pods (Sutherland et al.2001).

Processing of the raw material to obtain a final product of the quality and at a price that can be marketed is not as straightforward as it sounds and can require many years of development. In the case of Moringa oil, there is a lot of information published on the physical and chemical properties of the oil but very little if any on how the oil can be obtained. The majority of laboratory based studies use solvent extraction in order to be able to isolate the oil for analysis, however, in the real world solvent extraction is not necessarily the most cost effective method of production. Physical oil expression is a much more economical method but what pressure is the most effective? What temperature and moisture conditions provide maximum yield? Is the seed pressed whole with the shell or without? This is the information that is not yet reported and again requires practical trials to enable a solution to be found. This does not mean that the most effective and optimised process/cultivation practice, for example, has to be found prior to producing and selling a product, what it means is that, this element has to be addressed (Sutherland et al.2001).

\section{Market awareness}

The introduction of a new product within existing markets is never an easy job and requires an extensive knowledge of the market to which the product is being brought. Given that all the potential products for Moringa would be placed in already highly competitive markets, this is perhaps one of the most significant constraints to commercial development.

\section{Regulatory approval}

In general, it is not possible today to produce a new product on a commercial scale, bottle it, stick a label on it and offer it for sale to the general public. Almost all countries have regulatory authorities in place to ensure the quality and safety of products that are being offered for sale. Although there are many other constraints to commercialization that could be addressed, those that have been provided are considered to be the most relevant.

\section{REFERENCES}

Adesina, B. T. (2008). "Toxicity of Moringa oleifera (Lam.) Extracts to Oreochromis niloticus fingerlings and Juveniles" Unpublished. PhD Thesis University of Ibadan, Nigeria. 272pp. 
Adesina, B. T and Omitoyin, B. O (2011). "Potential of Moringa oleifera (Lam.) fresh root-bark extract as an organic piscicide in aquaculture pond management". Egyptian Journal of Biology. 13: 8-13.

Adesina, B. T; Omitoyin, B. O; Agbeja, B. O; Adebisi, L. A. and Adeyemo, A. A. (2008). " Effectiveness of Moringa oleifera Lam. Seeds as Natural Coagulant in Public Water Treatment. Obeche Journal 26 (1): 68-77.

Adesina, B. T.and Omitoyin, B. O. (2011). "Potential of Moringa oleifera (Lam.) fresh root-bark extract as organic piscicide in aquaculture pond management" Egyptian Journal of Biology .13:8-12.

Agbon, A. O., Ofojekwu, C. and Ezenwaka, I. (2004). "Acute Toxicity of Water Extract of Tephrosia vogelii Hook to Species Relevant in Aquaculture Ponds: Rotifers, Cyclops, Mosquito Larvae and Fish". Journal of Applied Ichthyology. 20: 521-525.

Akinbulumo, M. O., Fagbenro, O. A. and Fasakin, E. A. (2004). " Acute toxicity of ethanolic extract of Derris elliptica root to Oreochromis niloticus fingerlings". In: proceedings of International Symposium on Tilapia Aquaculture, Manilla, phillippines 1216 September. Accesed online http: //ag.arizona, edu/ azaque/ista/istab/istabweb/web/health. http on 10/24/2006. P223 228.

Berger, M. R., Habs, M., Jahn, S. A. A, and Schmahl, D. (1984). " Toxicological assessment of seeds from Moringa oleifera and Moringa stenopetale two highly efficient primary coagulants for domestic water treatment of tropical raw waters". East African Medical Journal. 61: 712716.

Bocek, A. (2004). "Eliminating Unwanted Fish". In: Water Harvesting and Aquaculture for Rural Development. Auburn University Publication, Alabama, USA. P1-11

Chiayvereesajja, S., Rittibhonbhun, N., Hongpromyart, M. and Wiriyachitra, P. (1997). "Toxicity of the Thia Piscicidal plant, Maesa ramentacea to freshwater fishes in ponds". Aquaculture 158(3/4):229-234.

Davies, W. D and Shelton, W. L (1983) "Sampling with toxicants". page 199-213. In: (Nielson, L. A. and Johnson, D.L. editors). Fisheries Techniques. American Fisheries Society, Bethesda, Maryland.

Devaraj, K.V., Keshavappa, G.Y., and Manissery, J.K. (1986)" Growth of grass carp (Tenopharyngodon idella) fed on two terrestrial fodder plants". Aquaculture and Fisheries Management 17(2): 123-128. 
Fafioye, O. O. (2001). "Lethal and Sublethal Effects of Extracts of Parkia biglobosa and Raphia vinifera on some freshwater Fauna". Ph.D. Thesis University of Ibadan, Nigeria. 216pp.

Fahey, J.W. (2005). "Moringa oleifera: A Review of the Medical evidence for its nutritional, Therapeutic and Prophylactic Properties." Part 1 Trees for life Journal. 1:5

FAO/NACA/WHO (1999). "Food safety issues associated with products from Aquaculture". Report of a joint FAO/NACA/WHO study group. WHO Technical Report Series. No. 883, WHO, Geneva, 55pp.

Francis, G., Makkar, H. P. S. and Becker, K. (2003). "Products from little researched plants as aquaculture feed ingredients". Accessed online: http://www.mamma.com on February, 14, 2004.

Fuglie, L. J (1999). "The miracle tree: The multiple attributes of Moringa", CTA, ACP and World Church Service Publication, Dakar Senegal.

Fuglie, L. J (2001). "The miracle tree: The multiple attribution of Moringa". CTA-ACP-EU and Church World Service publication. $2^{\text {nd }}$ edition.

GESAMP (1997). IMO/FAO/UNESCO/WMO/WHO/IAEA/UIV/UNEP. Joint Group of experts on the Scientific Aspects of marine pollution). "Towards safe and effective use of chemicals in coastal aquaculture." GESAMPReports Studies 65:42pp.

Grabow, W. O. K.; Slabert, J. L.; Morgan, W. S. G. and Jahn, S. A. A. (1985). "Toxicity and mutagenicity evaluation of water coagulated with Moringa oleifera seed preparations using fish, protozoan, bacterial, coliphage, enzyme and Ames Salmonella assays". Water South Africa 11(1): 914.

Lennon, R. E. Hunn, J. B., Schnick, R. A. and Burress, R. M. (1970)." Reclamation of ponds, Lakes, and streams with toxicant: a review". FAO Technical Paper 100.

Makkar, H. P. S and Becker K. (1997). "Nutrients and antiquality factors in different morphological parts of the Moringa oleifera tree". Journal of Agricultural Cambridge 128:311-322.

Mendieta-Araica, B. (2011). "Moringa oleifera as an alternative fodder for dairy cows in Nicaragua"Unpublished. PhD Thesis, Swedish University ofAgriculture Uppsala 118pp.

Nouman, W., Siddiqui, M. Tand Bastra, S. M. A(2012)"Moringa oleifera leaf extract: An innovative priming tool for rangeland grasses. Turkish Journal of Agriculture and Forestry 36:6575. 
Richter, N., Siddhuraju, P. and Becker, K. (2003)" Evaluation of Nutritional Quality of Moringa (Moringa oleifera Lam) Leaves as an alternative protein source for Nile tilapia (Orechromis niloticus L.) Aquaculture. 217 (1-4): 599-611.

Rowe, D. K. (2004)". Rotenonebased approaches to pest fish control in new Zealand". Science Conservation.131-142.

Sauveuret, A. S. and Broin, M (2010) "Growing and processing Moringa leaves." Moringa news/Moringa Association of Ghana. 36pp.

Schnick, R. A. (1974)"A review of the literature on the use of Rotenone in Fisheries". Fisheries control Laboratory.U.S Fish and Wildlife Service. 130pp.

Sutherland, J. P., Folkard, G. K. and Poirier, Y. L (2001). "Moringa oleifera.: the constraints to commercialization: Development Potential for Moringa products." Conference, Dar es Salaam, Tanzania, October $29^{\text {th }}$ - November $2^{\text {nd }}, 2001.4 \mathrm{pp}$.

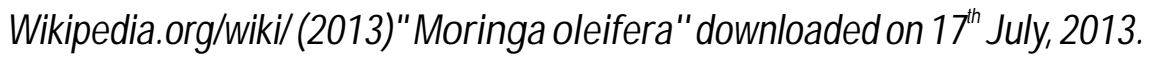

Wise, R. (2006). Moringa oleifera: Medicinal and socio-Economic uses. International course on Economic Botany, September, 2006. National Herbarium Leiden, Netherlands. 